\title{
Analysis of instruments for assessment of planned investments in water management
}

\author{
Andrzej Tiukało \\ Institute of Meteorology and Water Management, National Research Institute, Wrocław Branch, Parkowa Street 30, \\ 51-616Wroctaw, e-mail: andrzej.tiukalo@imgw.pl
}

\begin{abstract}
Integrated water resource management is a process oriented towards sustainable development through the shaping, allocation and monitoring of water resources, taking into account social, economic and environmental objectives. The water management policy realized in Poland is based on the idea of sustainable development and requires the use and application of appropriate evaluation tools in the process of socialized decision-making concerning the initiation and realization of investments with an impact on water management. This study discusses methods of assessment of planned investments, such as: cost and benefit analysis, and environmental impact assessment. These are balanced against the method recommended by the World Commission on Dams - A New Framework for DecisionMaking, as well as the main guidelines of the Positional Analysis (PA) method based on Ecological Economics. The latter opposes Neoclassical Economics, as well as Environmental and Natural Resources Economics. Integrated water resource management is a philosophy that informs the attitude that considers the balanced shaping of water resources as the most important objective of managerial activities. Those responsible for the decision making are obliged to take into consideration the wider context that accompanies such a process. They search for and invite many stakeholders to participate in the decision-making process, creating or utilizing the platforms for exchanging often opposing opinions that are present in democratic societies. In such activities, multi-criteria assessment may be a useful instrument, taking into consideration the coincidence of many, often equivalent, objectives, and utilizing a multi-element set of selection criteria. This paper emphasizes the functional values of the multi-criteria evaluation model for an investment, which is based on sustainable development objectives.
\end{abstract}

Key words: integrated water resources management (IWRM), evaluation of investments, sustainable development, instruments for decision-making.

Submitted 15 April 2013, received 27 May 2013, accepted 14 November 2013

\section{Introduction}

According to the currently valid water law (Official Journal of the Republic of Poland 2012), the aims of water resource management are: satisfying the needs of society and the economy; protection of water and the natural environment. These resources have particular importance within the following scope:

- securing adequate quantity and quality of water for households,

- protection of water resources against contamination or excessive exploitation,

- maintaining or improving the condition of water ecosystems and water dependant ecosystems,

- flood and drought prevention,

- supply of water for agriculture and industry,

- fulfilling the needs associated with tourism, sport and recreation,

- preparation of conditions for the use of water in the energy generation, transport and fishery sectors.

Among the basic areas of the management operations are investment initiation and planning, investment organization and supervision, and then monitoring and implementation of necessary corrections to the realized investments. According to the Deming cycle (Griffin 2010), planning reoccurs multiple times in the life-cycle of all investment
The results of inspections and the varying circumstances of the realized investment result in the undertaking of efforts aimed at the renewed planning of investments. The objective is to improve the quality of tasks and achieve enhanced results in activities accompanying the investment. We should also emphasise the crucial role of the assessment activities that accompany the decision-making process with regard to the selection of the investment variant aimed at meeting social, economic and ecological needs.

A report by the Ceres Coalition (Ceres 2011) - a large American organization that incorporates public and social companies and organizations that deal with environmental protection - raises the concern that by the year 2030 annual water delivery will fulfil only $60 \%$ of estimated demand, and that by $2025,2 / 3$ of humankind will inhabit areas with a limited availability of potable water. These statistics show the scale of the challenges in water management, which is defined as: all conscious and purposeful influence by mankind on water resources, with the purpose of fulfilling environmental, social and economic needs, either through utilisation of water resources, or through the prevention of damage they cause (KZGW 2011). Among these activities, one may distinguish investment planning that helps create water resources, and that which reduces damage caused by these resources. The author puts the following questions: "Does the decision- 
making process associated with investments in water management require a special approach? Are the instruments currently used in the decision-making process sufficient?"

\section{Integrated water resources management versus sustainable development policy}

Integrated Water Resources Management (IWRM), according to the International Network for Capacity Building in Sustainable Water Management (Cap-Net UNDP), is a process oriented at development through the modelling, allocation and monitoring of water resources used for social, economic and environmental needs (Cap-Net UNDP 2005, Cap-Net 2008). Such management is an alternative to sector water management, which is still often found in many countries. According to the Global Water Partnership, integrated water resources management (IWRM) is a challenge for conventional activities, attitudes and professional experiences. It substitutes deeply rooted management methods, which are the consequence of sector-based interests and expectations, for holistic management aimed at the benefit of all water consumers and users. This challenge is not easy, but taking the challenge is necessary to prevent a crisis from spreading rapidly (Cap-Net 2008).

IWRM is most of all a philosophy that develops the attitude that sustainable development of water resources is the most important objective of management activities. Such an attitude ensures that the participants of the decision-making process change their behaviour and take into consideration a wider context accompanying the process. They search for and invite many stakeholders into the decision-making process, forming or utilizing platforms of exchange of often opposing ideas that prevail in democratic societies.

The European Union water policy is based on these rules and manifested through:

- considering a catchment area as the basic area for all planning and decision-making activities,

- socialization of the decision-making process,

- integrated approach to surface and ground waters,

- balanced utilisation of water resources (people - economy - environment),

- treating water as the fundamental factor shaping the functioning of ecosystems,

- implementation of economic mechanisms in water management.

In Poland, the principal objective of the State's Water Policy by the year 2030, taking into account stage 2016 (KZGW 2011), is to provide people with common access to clean and healthy water, and to significantly reduce threats caused by floods and droughts. This should be realized in conjunction with the maintenance of good conditions of waters and water related ecosystems. At the same time it should as meet the justified needs for water in the economy, the improvement in territorial coherence and also the pursuit of mitigation of regional inequalities. It should also take into account the integration of the water environment with other branches of the national economy. Tab. 1 presents methods and means necessary for the accomplishment of the scheduled objective. They are discussed in the available version of the water policy of the state (KZGW 2011), with consideration of the IWRM rules.

Accomplishment of this most important objective from the point of view of society and its economic development, must be realized with the comprehensive integration of both protection and balanced water management with other areas of the European Community policy, such as: energy, transport, agriculture, fisheries, regional policy and tourism. Water policy should form the basis for the continuation of the dialogue and development of strategy in the further integration and development of individual areas of these policies (Directive No. 2000/60/WE of the European Parliament and European Council) - with the overall aim being the implementation of the idea of balanced management of the water system.

The World Business Council for Sustainable Development (WBCSD) advanced the thesis (in two reports: WBCSD 2008, 2010) that implies that future technological innovations will not ensure sustainable development. In order to accomplish this objective it will be necessary to transform the lifestyles and consumption models of present and future generations. The WBCSD Commission indicates, as a response to the following emerging challenges, the important role of the business sector in the creation of a new, sustainable model of consumption of goods and services.

- Increase in costs and reduction in the return rate as a result of growing competition for access to limited natural resources.

- Uncertainty resulting from, among other things, climate change, more frequent natural disasters with increasingly severe effects, as well as the depletion of reserves of some natural resources; these factors cause crises that are increasingly more unpredictable and severe in consequence.

- Increase in legislative regulations forced by societies that face environmental crisis and limitations in natural resources.

- Conflicts resulting from polarized political viewpoints that stem from different understandings of how to realize sustainable development policy.

Societies that are increasingly more conscious of environmental and social challenges will expect political and business elites to provide efficient solutions. To take on this challenge it is necessary that all social, political and economic stakeholders cooperate to create a new model of sustainable consumption. The WBCSD has presented a 5-element model of sustainable consumption, which will be the prerequisite of better living for 9 billion people with limited availability of natural resources (WBCSD 2011).

Among the conditions identified for success, it is worth noting the request to implement new measures of development in achieving objectives set by societies, companies and individual citizens. It is postulated that the progress 
Table 1. Integrated Water Resources Management according to the State's Water Policy

\begin{tabular}{|c|c|c|}
\hline Measures & Methods & Objective \\
\hline $\begin{array}{l}\text { Restoration and maintenance, to a feasible ex- } \\
\text { tent, of good condition and potential of surface } \\
\text { and ground waters, within the conditions of the } \\
\text { planned development }\end{array}$ & \multirow{3}{*}{$\begin{array}{l}\text { Accomplishment and maintenance of good } \\
\text { condition and potential of waters and water- } \\
\text { related ecosystems }\end{array}$} & \multirow{16}{*}{$\begin{array}{l}\text { Provision of common access to clean and } \\
\text { healthy water and significant reduction in } \\
\text { threats caused by floods and droughts, com- } \\
\text { bined with maintenance of good condition of } \\
\text { waters and water-related ecosystems, in fulfil- } \\
\text { ling water-related needs of a country's econo- } \\
\text { my, enhancement of territorial coherence and } \\
\text { effort to balance interregional disparities }\end{array}$} \\
\hline $\begin{array}{l}\text { Reduction in inflow of contamination to sur- } \\
\text { face and ground waters }\end{array}$ & & \\
\hline $\begin{array}{l}\text { Reduction in retention loss and its restoration, } \\
\text { taking into account natural and technical meth- } \\
\text { ods }\end{array}$ & & \\
\hline $\begin{array}{l}\text { Determination of real needs of people and } \\
\text { a state's economy in relation to water, in order } \\
\text { to secure access to adequate amount of water } \\
\text { resources }\end{array}$ & \multirow{6}{*}{$\begin{array}{l}\text { Securing access to water resources to fulfil } \\
\text { needs of people, the natural environment and } \\
\text { other socially and economically justified needs }\end{array}$} & \\
\hline $\begin{array}{l}\text { Rationalization of fulfilment of needs of peo- } \\
\text { ple, the economy and natural environment in } \\
\text { relation to water, taking into account threats } \\
\text { resulting from a deficiency of water }\end{array}$ & & \\
\hline $\begin{array}{l}\text { Implementation of formal and legal mecha- } \\
\text { nisms that enable rational management of wa- } \\
\text { ter resources }\end{array}$ & & \\
\hline Rationalization of water use (water savings) & & \\
\hline $\begin{array}{l}\text { Increase in share of hydropower generation in } \\
\text { the country's energy balance }\end{array}$ & & \\
\hline $\begin{array}{l}\text { Improvement in standards and development of } \\
\text { inland navigation routes }\end{array}$ & & \\
\hline $\begin{array}{l}\text { Implementation of policy within the scope of } \\
\text { flood risk management }\end{array}$ & \multirow{4}{*}{$\begin{array}{l}\text { Reduction in negative effects of floods and } \\
\text { droughts, and minimisation of risks of occur- } \\
\text { rence of extraordinary situations }\end{array}$} & \\
\hline $\begin{array}{l}\text { Improvement in efficiency of protection of citi- } \\
\text { zens before floods and from effects of drought, } \\
\text { through application of effective technical ac- } \\
\text { tivities }\end{array}$ & & \\
\hline $\begin{array}{l}\text { Improvement in utilisation and enhancement of } \\
\text { efficiency of non-technical methods of mitiga- } \\
\text { tion of effects of flood and drought }\end{array}$ & & \\
\hline $\begin{array}{l}\text { Improvement in safety of hydrotechnical facili- } \\
\text { ties }\end{array}$ & & \\
\hline $\begin{array}{l}\text { Elaboration and stage-based implementation in } \\
\text { the institutional transformation of water man- } \\
\text { agement }\end{array}$ & \multirow{3}{*}{$\begin{array}{l}\text { Implementation of an integrated system of } \\
\text { management of water resources }\end{array}$} & \\
\hline $\begin{array}{l}\text { Development of organizational, legal and eco- } \\
\text { nomic instruments of integrated management } \\
\text { of water resources }\end{array}$ & & \\
\hline $\begin{array}{l}\text { Creation of an educational system in the field } \\
\text { of water management }\end{array}$ & & \\
\hline
\end{tabular}

in realization of national sustainable development programmes should be measured by an index that takes into account the conditions of the society and environment. The index that is currently in use - gross domestic product (GDP) - should be replaced by a relevant index which takes into account activities that strive to build environmental and social capital, such as environmental protection and restoration, education, health prevention. The measure of national success should therefore analyze the consumption level in the context of sustainable development, and should both have a quantitative and qualitative dimension. We should take note that many organizations have used a balanced scorecard for many years as the method of assessment of their development (Kaplan 1996). Such a method of measuring an organization's development may therefore be a route marker when searching for a measure of the development of societies.

\section{Instruments for water management policy}

Making investment decisions in water management based on the policy of sustainable development requires the elaboration of an efficient method for the effective allocation of resources (perceived as an allocation of natural, human, social and man-made capital). This process is carried out in order to achieve the highest value in the categories of goods and services while at the same time retaining the demand for sustainable development.

Cost and benefit assessment is a method of assessment of investments and programmes realized within the frame- 
work of the public sector. This instrument facilitates the tasks of those managers working in the public sector who make decisions associated with granting access to selected public goods and services, making public investments and also with regard to the regulation of operations in private markets (Tiukało 2010). This method serves as a tool that enables the comparison of the efficiency of alternative applications of assets in a scheduled investment. "The key conceptions, which lay the foundations for the CBA assessment, refer to the cost evaluation (expenditure) and benefits (results) of projects. With reference to the results, the concept of the willingness to pay applies here; while the assessment of the degree of the involvement of assets (expenditure made in order to realize the project) is realized through the alternative expenses approach « (Drobniak 2002).

This method assumes the necessity of expressing all costs and benefits associated with a project in monetary values. The basic CBA rule is the application of the criterion, by which an investment of a programme should then, and only then, be realized, when:

$$
\text { Net profit }=\text { total benefits }- \text { total costs }>0
$$

i.e. only when the total benefits are higher than total costs. Since costs and benefits are most often reflected in the form of streams distributed in time, the updating of the value of each of these is calculated by the application of the discount rate relevant to this purpose. The result of the subtraction of the updated benefits and costs is the economic net present value (ENPV) of the scheduled project. This means that an investment associated with water management should be realized if the benefits of all concerned (discounted taking into account the total investment's life cycle) are higher than total costs (ENPV $>0)$. In order to achieve the maximum economic efficiency of decisions taken within opposing variants, we select the variant with the highest economic net present value, while in cases of decisions made under the circumstances of limited assets, it is necessary to select such a combination of public programmes that will allow the maximization of the value of net profits while taking into account the existing limitations. In the case of flood protection, the author suggests reformulating the question "Should we, or should we not, build the flood protection system « into the question: "What is the optimum catchment area that requires flood protection? « (Tiukało 2010).

We can distinguish the following stages in the process of the assessment of investments with the use of the cost and benefits assessment (CBA):

1. determination of the set of methods for accomplishing the project's objectives,

2. determination of the project's stakeholders, with respect to benefits accomplished and costs incurred; depending on the range of the project, it becomes possible to apply various types of perspective, beginning with the global, then national, through regional and local,
3. calculation of effects, and selection of indicators that allow their quantitative measurement,

4. quantitative forecasting of effects during the project's life cycle; assessments of this type are carried out for each stakeholder of the project and concern costs as well as benefits associated with the project within a time unit (most often 1 year),

5. introduction of cash values for each type of effect (this means that individual categories of costs and benefits must be reflected in cash, particularly with respect to the following categories: time-saving, reduction in the mortality rate, reduction in the number of car accidents, and environmental pollution),

6. discounting of costs and benefits in order to receive a present value; the discounting mechanism is identical to that utilized in the investment's financial assessment, although the discount rate is referred to as the economic or social discount rate,

7. calculation of the economic net present value resulting from the project ENPV for each alternative - for the determination of differences between ENPV values of individual projects,

8. execution of a vulnerability study that takes into account the uncertainty associated with the tasks listed in point 3 and point 4 .

Currently, while working on the application of the CBA method, it is apparent that there is far-reaching specialization in relation to fields that are key areas in the utilisation of social and economic analyses. At the same time, water management does not belong to those areas of investment activity that possess their own standards for determining unit prices for the effects of investments carried out in this area. The author's experience confirms the fact that in CBA assessments of planned investments in water management, the list of analyzed costs and benefits depends solely on an expert's creativity. Therefore, the results of such analyses are difficult to acknowledge as reliable and comparable with results of analyses conducted for other, similar, investments. In fact, there are efforts being undertaken to expand the CBA range and to incorporate social and environmental aspects within it. However, these have seldom led to a comprehensive determination of social and environmental impacts, and have usually been limited to taking into account the costs of relocation and the mitigation of impact on the natural environment (WCD 2000). The World Commission on Dams formulates many critical remarks associated with the accuracy of the utilisation of CBA in reference to the evaluation of proposed large dam projects. The Commission points out that influences of a wider political and economic situation also penetrate the CBA process. This view is shared by Peter Söderbaum (2007). In certain cases, the initial engagement in a given project of some political forces or institutions becomes the decisive factor, so that economic studies conducted thereafter are aimed at the justification of decisions that have already been made. 
Over the last two decades of the 20th century, Environmental Impact Assessment (EIA) became one of the main tools employed to include social and ecological influences in assessments of planned investments. An environmental impact assessment usually constitutes a step in a process that aims to issue environmental conditions and decisions approving the realization of an investment. Such a process is meant to coordinate the planned investments with a society and with relevant administrative authorities, and is based on the submitted forecast of environmental impact of these investments. Preparation of the environmental impact assessment for a planned investment is therefore only one of the components of this process, which is concludes with a positive or negative administrative decision. Proceedings are initiated upon application by the entity that commences the realization of the investment, and the application should be accompanied by, among other things, information on the planned investment or an environmental impact statement (EIS; EC 2001a, b, c).

In proceedings concerning environmental impact assessments, an administrative institution studies and evaluates direct and indirect environmental impact of a specific investment, as well as people's health and living conditions, possibilities and methods of prevention and mitigation of negative environmental impact, and also the required range of monitoring. Social participation is an important element in the decision-making process concerning environmental conditions, as stipulated in legal regulations of the Environmental Law Act. The objective of social participation is to contribute to an increased sense of affiliation with a local community, and sense of responsibility for public affairs amongst all the stakeholders of a process, i.e. institutions conducting the process, opiniongiving and coordinating institutions, applicants, as well as various social groups interested in a project's results and impact. This also contributes to an enhanced knowledge of the effects of a planned investment and its impact on the environment.

Proceeding with environmental impact assessment is, however, not the correct tool for supporting decisionmaking in investments at the stage of selection of the best option of investment, since environmental impact assessment is meant to serve as a methodology for the recognition of impact and applicable means of mitigation, rather than as a tool for including ecological and social aspects in the ultimate selection of a project and its subsequent specific shape. Even if the environmental impact assessment includes the analysis of options, it is conducted without the participation of stakeholders. Social participation in the process is late and based on previously elaborated experts' opinions. An environmental impact statement is conducted upon an applicant's request by an expert who is conscious of who is going to receive his work. The statement therefore mainly includes compensatory measures or mitigation of planned impacts - the objective here is to reach an acceptable level with regard to the effects of project realization, while the decision actually concerning this realization has been practically made by the project sponsor (investor) (WCD 2000, Söderbaum 2007). Furthermore, allegations are raised that environmental impact assessment acts under significant limitations - for both political reasons and administrative pressures resulting from project realization schedules that are perceived by the investor as potential delays in the realization of investment.

Cost and benefit assessments and environmental impact assessments have properties that justify the formulation of a critical evaluation of their usefulness as efficient tools in the selection of the most favourable investments that serve sustainable development, for the following reasons:

1. experts arbitrarily identify project stakeholders, the range, and also the scope of impact of the planned investment on individual stakeholders,

2. experts arbitrarily determine monetary indicators to all economic and non-economic values that accompany an investment,

3. these are based on the neoclassical assumption that an Economic Person makes decisions, guided exclusively by the motivation to accomplish maximum benefit,

4. project sponsors have influence on experts' attitudes, and thus on the results of assessments,

5. while selecting a variant of the investment, a project's discounted economic value is taken into consideration without analyzing the share of intra-generational costs and benefits (by individual stakeholders),

6. an arbitrarily accepted value of economic discount rate determines the intergenerational share of costs and benefits that accompany a project.

In order to support decisions that contribute to sustainable development, it is therefore necessary to search for instruments that enable the evaluation of planned investments, and which:

1. will consider the wide spectrum of social, environmental, cultural and economic aspects of decisions made,

2. will create the space for monetary and non-monetary indices, formed according to the ideological attitudes of investment stakeholders,

3. will take into consideration the behaviour of a "Political Economic Person" and of a "Political Economic Organizations", who make decisions based on their own political opinions, taking into account their interactions with the environment,

4. will identify investment stakeholders and develop a social and transparent process of decision-making, through the involvement of stakeholders at the earliest possible stage of the decision-making process, so that they may participate in the identification of needs and the formulation of assessment criteria for alternative solutions,

5. will guarantee cooperation between sponsors, stakeholders and experts in the process of identifying the most favourable methods for the fulfilment of identified needs, while accepting the variety of opinions and subjectivity of evaluation by individual participants within the decision making process. 
For this reason, tools are being sought that enable the assessment of investments contributing to the sustainability assessment model (SAM), and which will constitute a response to the epistemological and ethical uncertainty of conducted analyses. It should be emphasized that the intention with regard to the formulation of tools for sustainability assessment models was not to create fixed procedures, but rather to build a platform for discussion and the development of methodology by sponsors, stakeholders and experts - and this progress depends on the opinions of all authors of the decision-making process (Bebbington et al. 2007). SAM is a tool for supporting stakeholders in their active participation in the assessment of a planned investment, and the assessment of its impact on sustainable development. It was created by British Petroleum for the social assessment of the impact of planned investment, and takes into consideration four main areas: economics, the environment, natural resources being exploited, and social capital. Identified direct and indirect impacts are expressed by monetary indices and with the description of identified phenomena or processes, as well as with the use of control lists (Bebbington et al. 2007). SAM is therefore a useful tool for the evaluation of a planned investment, and can be used to offer an improvement in the democratic method of decision-making, while retaining basic principles for conducting social negotiations and being an ideologically open model (Söderbaum 2007). It contributes to:

1. offering new possibilities in the assessment of investments - free of the weaknesses of traditional evaluation models,

2. supporting social actors of the decision making-process in recognizing the decision-making mechanisms,

3. promoting the rationalization of decision-making (within the framework of declared opinions, regardless of the diversity of declared opinions),

4. supporting dialogue and the responsibility of stakeholders (enabling adequate forums for expressing opinions),

5. encouraging people and organizations to critically analyze the behaviour of organizations and societies,

6. clarification of the motivations of decisions that have been made,

7. protection against various forms of dominance by stakeholders, and protection in the field of disputable areas (Brown 2009).

The World Commission on Water Dams guidelines for decision-making (WCD 2000) take into consideration the above requirements and are based on the following strategic priorities:

1. Social acceptance of key decisions is a necessary prerequisite for fair and sustainable management of water and energy resources. The decision-making procedures and mechanisms should be applied so that these enable conscious participation of all groups of society and ensure the demonstration of acceptance of key decisions.

2. Comprehensive evaluation of options, initiated by a comprehensive and participatory process of determination of needs and formulation of objectives of a planned investment, as well as the generation of many possible diverse investment options. In the assessment process social and ecological aspects are of equal significance to economic and financial factors.

3. Better utilisation of the existing dams (more widely all water buildings and facilities) - because in managing water management facilities we should aim at their continuous adaptation to changing circumstances, remembering also to make sure that such changes, as far as possible, solve outstanding social problems.

4. Protection of rivers and sources of people's livelihoods - this consists of the adaptation in the decisionmaking process of investment; decisions preventing influences; and, from a later perspective, minimisation and removal of aspects harmful to health and the coherence of the river system.

5. Acknowledgement of authorizations and division of benefits. Mutual negotiation with people affected by disadvantageous influences leads to mutually agreed and legally-binding arrangements concerning the mitigation of effects of, and actions supporting, development.

6. Ensured completion of arrangements, demonstrated by compliance with adequate regulations, criteria and guidelines, as well as negotiated agreements specific to a given project at all critical stages of investment planning and realization.

7. Mutual utilisation of rivers for the benefit of peace, development and safety - this requires arrangements to be made between countries concerning the principles of use and management of resources, promoting mutual benefits within the framework of regional cooperation and peaceful collaboration.

The World Commission on Dams guidelines for making decisions within a decision-making process distinguish five key decision points of special significance for a project's end results (WCD 2000). The decision-making process concerning the selection of a realized option distinguishes the evaluation of needs and the analysis of variants, and is concluded by selection of one of these. Making such decisions requires the identification of all stakeholders of the project, and the opening of dialogue channels between the parties concerned.

Positional Analysis (PA) is a methodology, proposed by Peter Söderbaum, for the evaluation of a planned investment. It encourages the elaboration of many independent evaluation documents concerning a planned project - these will express the attitudes and opinions of stakeholders representing different attitudes and political beliefs. Differing assessments of a planned investment allow the exposure of diverse systems of values, viewpoints concerning the needs and methods of fulfilment, and the effects of project realization in the context of differentlyperceived forms of sustainable development. Participants in the decision-making process mutually learn about all 
relevant opinions, create coalitions of partners with similar opinions, and are in positions of conflict with groups representing different opinions. An unquestionable advantage of this method is the disclosure of the decision-making mechanisms accompanying this process, including all conflicts and limitations, as well as the complexity of mutually penetrating aspects that influence the assessment of investments (Söderbaum 2000, Brown 2009). Söderbaum encourages the use of monetary and non-monetary indicators for evaluating investments.

Positional Analysis is the result of Ecological economics - i.e. a process that analyses and describes economic, social and ecological processes that affect the realization of sustainable development. Ecological economics emerged in reaction to criticism of neoclassical economics and refers to the ecological paradigm of economics, and sits therefore in opposition to economics of the environment and natural resources based on the paradigm of environmental economization. In development of ecological economics, the important statement is that individual choices are determined by a political context. Therefore, a neoclassical economic person who makes rational and predictable decisions has been replaced by a political economic person (Söderbaum 2000), i.e. a human being who has established opinions (in the widest meaning of this word), who makes choices best for him in accordance with these opinions, but that these choices are also motivated by concern for the society to which he belongs.

All decisions made by business and non-business organizations, just as those made by political economic organizations (PEOs), are also determined by their declared ideology, which may be more or less expressly articulated. Consequently, the influence of the process of production and consumption of a selected product will be considered by ecological economics across many dimensions (including: employment, natural resources, landscape etc.) (Söderbaum 2007).

The above guidelines indicate that economics is in this case very widely perceived and, among many factors with impact on economic decisions, politics is also relevant. It is one step from understanding the significance of authorities in decision-making to accomplishing full political agreement in principal questions on the implementation of sustainable development. Ecological economics reco-gnizes the need for a new approach to the decision-making process, and towards working for the benefit of sustainable development (Sustainability Assessment Model SAM) (Bebbington et al. 2007). In this case democratization plays the key role, as it is the prerequisite for unfettered alterna-ting influences related to the methods of fulfilment of key social needs of many stakeholders participating in decision-making, as well as being essential for the transparent process of the selection of social development methods. Political debate carried out and based on these principles ensures the achievement of an increasingly higher level of social responsibility on the part all of its stakeholders.

\section{Conclusions}

The modelling of a system transforming environmental, social and economic needs into products (water management services) that fulfil these needs should take into consideration all processes contributing to the accomplishment of a proper product that ensures the sustainable development of a society. Amongst these processes, one should distinguish processes for the definition of needs and corresponding project objectives; the selection of the most favourable method for fulfilling needs; as well as management of project scope, management of time and costs of its preparation (planning); management of realization and exploitation; the quality of processes and products; and also the management of uncertainty and risk accompanying an investment.

Project sponsors have been incorporating stakeholders (that is people, groups and social and economic organizations that may be affected by the investment in question) into the decision-making process over the last several years. Depending on the understanding of democracy and the participatory contribution of society in the decisionmaking process, current practices are evaluated more or less critically. A serious attitude to democratic mechanisms favours the formulation of expectations for social participation in the decision-making process at the earliest possible stage of project definition. The realization of such a demand is supported by procedures of project evaluation that are part of the methods of assessment of influence of planned projects on sustainable development (Sustainability Assessment Model SAM). Amongst the available tools that ensure the participation of stakeholders in the decision-making process, particular attention should be paid to Positional Analysis (PA), formulated by Söderbaum, which encourages the development of many independent evaluating documents of a planned project, and constitutes the emergence of attitudes of stakeholders representing different political beliefs.

While studying an investment process one should be aware of specialist knowledge in the fields of sociology, ecology, economics and finance, but also in the field of administrative proceedings, and also the many legal regulations associated with spatial development, environmental protection etc. Integrated knowledge is necessary for the management of a social process of formulating needs; the participatory definition of functional and usable programmes; the preparation of necessary arrangements and documents necessary to launch a project; and the maintenance of sustainable development, the perception of which should be at all stages agreed with a project's stakeholders.

Ecological economics is a science that analyses and describes economic, social and ecological processes participating in the realization of sustainable development, and therefore the results of evaluation by Ecological economists should be taken into consideration in studies on the decision making-process associated with investments contributing to the integration of water resources management. 
Making decisions in Water Management that correspond with the requirements of the integrated management of water resources requires an interdisciplinary approach to processes of initiation, preparation and realization of programmes, and also to large investment undertakings. The strategic priorities defined by the World Commission on Dams, which constitute the basis for guidelines in decision-making associated with water management and energy related investments, should also be subject to assessment while defining decision-making procedures applied within the framework of integrated management of water resources, objectives of which are defined in the national water management policy by 2030 .

CBA assessment focuses on one objective - the improvement in efficiency, and utilizes one criterion - the maximization of net profit. For this reason, it is an imperfect instrument for use in the decision-making process associated with public projects that require consideration of a wide spectrum of objectives of various social groups, and which require the application of a set of assessment criteria of the investments under consideration.

Integrated water resources management is a philosophy that informs the attitude that considers the balanced shaping of water resources as the most important objective of managerial activities. Those responsible for the decision-making are obliged to take into consideration the wider context that accompanies such a process. They search for and invite many stakeholders to participate in the decision making process, creating or utilizing platforms for exchanging often conflicting opinions that exist in democratic societies. In such activities multi-criteria assessment may be a useful instrument, as it takes into consideration the coincidence of many often equivalent objectives, and utilizes a multi-element set of selection criteria.

In the models of assessment of investment undertakings contributing to sustainable development (Sustainability Assessment Models SAM), it is preferable to apply a multi-criteria assessment, which allows for the identification of direct and indirect impacts and for their expression not only through monetary indicators, but also through the description of identified phenomena or processes, as well as with the use of control lists. For the creators of this category of decision-making models it is important that the participants in the decision-making process democratically participate in the determination of objectives and criteria of the multi-criteria assessment. Participants in the decision-making process will be successful when they make selections respecting their own, often conflicting political opinions, often taking into consideration many different variants, with the use of previously developed assessment criteria.

The additional benefit resulting from use of multicriteria assessment in the participatory process of decision making in the water management sector is the strengthening of civil society through the improvement in the social potential of citizens participating in the process.

\section{Bibliography}

Bebbington J., Brown J., Frame B., 2007, Accounting technologies and sustainability assessment models, Ecological Economics, 61, 224-236

Brown J., 2009, Democracy, sustainability and dialog accounting technologies: Taking pluralism seriously, Critical Perspective on Accounting, 20, 313-342

Cap-Net UNDP, 2008, Economics in Sustainable Water Management, Training Manual and Facilitator's Guide

Cap-Net UNDP, 2005, Integrated Water Resources Management Plan, Training Manual and Operational Guide

Ceres, 2011, The Ceres Aqua Gauge: A framework for 21st century water risk management

Drobniak A., 2002, Zastosowanie analizy kosztów i korzyści w ocenie projektów publicznych, Akademia Ekonomiczna w Katowicach, 215 pp

Dziennik Ustaw Rzeczpospolitej Polskiej, 2012, Obwieszczenie Marszałka Rzeczypospolitej Polskiej z dnia 10 stycznia 2012 r. w sprawie ogłoszenia jednolitego tekstu ustawy - Prawo wodne, Warszawa, 9 lutego 2012 r, Pozycja 145 (eng. Official Journal of the Republic of Poland, 2012, Announcement of the Speaker of the Republic of Poland, from 10 January 2012 concerning release of the uniform wording of the act of law - Water law. Warsaw, 9 February 2012, item 145)

European Commission, 2001a, Guidance on Environmental Impact Assessment, EIS Review,

European Commission, 2001b, Guidance on Environmental Impact Assessment, Scoping

European Commission, 2001c, Guidance on Environmental Impact Assessment, Screening

Griffin R.W., 2010, Podstawy zarządzania organizacjami, Wydawnictwo Naukowe PWN, Warszawa, pp. 802

Kaplan R.S., Norton D.P., 1996, The Balanced Scorecard: Translating Strategy into Action, Harvard Business Review Press, $336 \mathrm{pp}$

KZGW, 2011, Polityka wodna państwa do roku 2030 z uwzględnieniem etapu 2016 (Water Policy of the State until 2030, with stage 2016 taken into consideration)

Söderbaum P., 2000, Ecological Economics. A Political Economics Approach to Environmental and Development, arthscan, London, $152 \mathrm{pp}$

Söderbaum P., 2007, Issues of paradigm, ideology and democracy in sustainability assessment, Ecological Economics, 60, 613-626

Światowa Komisja Zapór Wodnych, 2003, Zapory a rozwój. Nowe wytyczne dla podejmowania decyzji - Raport Światowej Komisji Zapór Wodnych, KLUB GAJA, BielskoBiała

Tiukało A., 2010, Analiza efektywności projektów przeciwpowodziowych, Zarządzanie zasobami wodnymi w dorzeczu Odry, PZITS, 894, 39-53

Tiukało A., 2012, Ekonomia Ekologiczna dla planowania decyzji inwestycyjnych, Naturalne i antropogeniczne przemiany jezior, Międzynarodowa Konferencja Limnologiczna

WBCSD, 2008, Sustainable Consumption Facts and Trends, Report, World Business Council for Sustainable Development 
WBCSD, 2010, Vision 2050, World Business Council for Sustainable Development

WBCSD, 2011, A vision for sustainable consumption. Innovation, collaboration, and the management of choice, World Business Council for Sustainable Development
WCD, 2000, Dams and Development: A new Framework for Decision-Making - Report of the World Commission on Dams 